\title{
OPTIMALISASI PEMANFAATAN MEDIA BERBASIS IT DALAM PEMBELAJARAN MELALUI KEGIATAN SUPERVISI AKADEMIK OLEH KEPALA SEKOLAH
}

\section{OPTIMIZATION OF THE UTILIZATION OF IT-BASED MEDIA IN LEARNING THROUGH ACADEMIC SUPERVISION ACTIVITIES BY THE PRINCIPAL}

\author{
I Ketut Gede Arsa* \\ SMP Negeri 3 Pupuan, Tabanan, Bali, Indonesia \\ *Email Penulis korespondensi: Tu...arsagede@gmail.com
}

\begin{abstract}
Abstrak
Penelitian tindakan sekolah ini bertujuan untuk mengetahui pemanfaatan media berbasis IT dalam pembelajaran pada guru SMP Negeri 3 Pupuan. Subjek penelitian merupakan guru SMP Negeri 3 Pupuan sebanyak 15 orang, objeknya adalah pemanfaatan media IT dalam pembelajaran melalui kegiatan supervisi akademik kepala sekolah. Intrumen berupa pedoman observasi dan angket. Data yang diperoleh dianalisis secara deskriptif kualitatif. Kriteria keberhasilan dalam penelitian ini adalah minimal $80 \%$ guru mampu memanfaatkan media IT dalam pembelajaran serta minimal $80 \%$ guru sering menggunakan media IT. Hasil yang diperoleh peningkatan pemanfaatan media IT oleh guru dalam proses pembelajaran meningkat dari pra siklus sebanyak 6 orang (60\%) guru memanfaatkan media IT dalam pembelajaran meningkat pada siklus I menjadi 14 orang $(93,33 \%)$ guru yang memanfaatkan Media IT dalam Pembelajaran dan pada siklus II sejumlah 14 orang $(93,33 \%)$ guru yang memanfaatkan Media IT dalam pembelajaran. jika dilihat dari frekuensi pemanfaatan media IT dalam pembelajaran dari siklus I sebanyak 9 0rang guru yang sering memanfaatkan media IT dan meningkat pada siklus II menjadi 12 orang guru (80\%) kesimpulan penelitian ini adalah pemanfaatan media IT dalam pembelajaran dapat dioptimalkan melalui kegiatan supervisi yang dilakukan secara berkala oleh kepala sekolah termasuk juga berkolaborasi antar guru SMP Negeri 3 Pupuan.
\end{abstract}

Kata-Kata Kunci: Media IT; Pembelajaran; Supervisi

\begin{abstract}
This school action research aims to determine the use of IT based media in learning at SMP Negeri 3 Pupuan teachers. The research subjects were 15 teachers of SMP Negeri 3 Pupuan, the object was the use of IT media in learning through the supervision of the principal. Instruments in the form of observation guidelines and questionnaires. The data obtained were analyzed descriptively qualitatively. The criteria for success in this study are at least $80 \%$ of teachers are able to use IT based media in learning and at least $80 \%$ of teachers often use IT media. The results obtained that the increase in the use of IT based media by teachers in the learning process increased from the pre-cycle as many as 6 people $(60 \%)$ teachers used IT based media in learning increased in the first cycle to 14 people $(93.33 \%)$ teachers who used IT based Media in Learning and in the second cycle a total of 14 people $(93.33 \%)$ teachers who use IT based media in learning. when viewed from the frequency of using IT based media in learning from the first cycle as many as 9 0rang teachers who often use IT media and increased in the second cycle to 12 teachers $(80 \%)$ the conclusion of this study is the use of IT media in learning can be optimized through supervision activities carried out periodically by the principal, including collaborating among teachers of SMP Negeri 3 Pupuan.
\end{abstract}

Keywords: IT Media; Learning; Supervision

\section{PENDAHULUAN}

Menurut Vandini (2015) belajar adalah suatu proses perubahan individu baik tingkah laku maupun perkembangan pada pengetahuan ataupun pribadi yang didasari dari sebuah usaha dalam mencapai suatu tujuan dalam berinteraksi dengan lingkungannya. Dalam proses 
perubahan tingkah laku tersebut seorang siswa memerlukan bimbingan atau tuntunan seorang guru agar pembelajaran yang dilakukan dapat mengarah kepada tujuan yang telah ditetapkan. Dalam hal ini guru juga harus mampu mengembangkan dirinya guna mengimbangi proses belajar siswa sesuai dengan kondisi dan keadaan siswa. Menurut Iskandar (2015) guru memiliki peranan yang besar dalam mengarahkan peserta didik serta guru harus selalu inovatif dalam proses pembelajaran agar dapat mengarahkan siswa kearah yang lebih baik.

Selain faktor guru, keberhasilan suatu proses pembelajaran juga dipengaruhi oleh faktor lainnya. Menurut Anisa dan Yulianto (2017) Terdapat tiga komponen yang berpengaruh dalam pelaksanaan pembelajaran antara lain metode pembelajaran, media pembelajaran, dan penataan lingkungan tempat belajar. Ketiga komponen tersebut dapat membantu pencapaian tujuan dan pelaksanaan pembelajran sehingga memberikan hasil yang maksimal bagi peserta didik, salah satu komponen yang berperan seperti dijelaskan tersebut adalah media pembelajaran. Menurut Audie (2019) Penggunaan media dapat membantu peserta didik untuk menyerap materi sama dengan yang lainnya sehingga menimbulkan persepsi yang sama antar siswa yang satu dengan yang lainnya dan dapat meningkatkan hasil belajar peserta didik lebih maksimal. Sehingga dengan media pembelajaran yang baik akan membantu mengarahkan peerta didik dalam upaya memahami materi yang disampaikan guru dalam pembelajaran.

Penggunaan media pembelajaran juga selalu berkembang sesuai dengan kebutuhan guru dan siswa serta perkembangan yang ada dalam masyarakat. Penggunaan media konvensional berupa buku teks juga mulai diimbangi dengan media pembelajaran yang bersifat kekinian. Menurut Nurseto (2011) media pembelajaran adalah wahana penyalur pesan dan informasi belajar. Ketika media pembelajaran tersebut difungsikan sebagai wahana untuk penyalur pesan dan informasi, peran media pembelajaran sangat penting untuk mengkomunikasikan maksud yang disampaikan oleh guru sesuai dengan materi yang terkait agar dapat diterima dengan baik oleh siswa. Media yang digunakan sudah pastinya menarik dan sesuai kebutuhan. Ini sesuai dengan pendapat dari Abdullah (2016) yang menyatakan bahwa media yang menarik dapat membantu siswa dalam memahami materi yang diberikan guru dalam pembelajaran.

Perkembangan teknologi pada masa sekarang ini juga berpegaruh terhadap media yang digunakan oleh para guru dalam pembelajaran. Pemanfaatan media yang digunakan selain berpengaruh dalam hal penyerapan materi juga dapat memberikan pengalaman kepada siswa untuk bekal mereka kedepannya baik dalam pendidikan yang lebih tinggi atau dunia kerja. Guna menyesuiakan dengan perkembangan masyarakat guru sebaiknya memanfaatkan media berbasis IT, media pembelajaran berbasis IT atau yang juga dikenal dengan media berbasis (ICT) adalah sarana penyebaran informasi yang berupa perangkat keras, perangkat lunak, sistem jaringan dan infrastruktur komputer maupun telekomunikasi agar data dapat disebar dan di akses secara global (Rusman, 2012). Secara sederhana media pembelajaran berbasis IT dapat dikatakan sebagai media pembelajran yang memanfaatkan perangkat komputer atau sejenisnya dalam pembelajaran. contoh penggunaan media pembelajaran berbasis IT dapat berbentuk file slide Power Point, gambar, animasi, video, audio, program CAI (computer aided instruction), program simulasi, dan lain-lain(Suryani, 2016). Pemanfaatan media pembelajaran berbasis IT sangat diperlukan guna menarik peserta didik dalam pembelajaran sehingga tercapainya tujuan pembelajaran yang sudah ditetapkan.

Pemanfaatan media berbasis TI ini sudah sebaiknya diterapkan di sekolah-sekolah di Indonesia termasuk juga pada SMP Negeri 3 Pupuan guna membantu guru dalam pembelajaran serta membantu siswa dalam memahami pembelajran yang dilaksanakan. Berdasarkan hasil observasi awal terkait dengan pemanfaatan media berbasis IT pada SMP Negeri 3 Pupuan dapat dilihat pada tabel 1. 
Tabel 1. Data Pemanfaatan Media IT dalam Pembelajaran pada SMP Negeri 3 Pupuan

\begin{tabular}{cccc}
\hline No & Pemanfaatan Media Pembelajaran & Jumlah & Persentase \\
\hline 1 & Memanfaatkan Media IT & 9 Orang & $60 \%$ \\
2 & Tidak Memanfaatkan Media IT & 6 Orang & $40 \%$ \\
\hline Jumlah Guru & 15 Orang & $100 \%$ \\
\hline
\end{tabular}

Berdasarkan Tabel 1. di atas, dapat diketahui bahwa jumlah guru yang memanfaatkan media pembelajaran berbasis IT hanya berjumlah $60 \%$. Jika dilihat idealnya di masa perkembangan IT seperti sekarang ini sudah seharusnya lebih banyak guru dapat memanfaatkan media tersebut apalagi sudah ditunjang berupa fasilitas seperti laptop yang dimiliki termasuk juga alat penunjang lainnya seperti jaringan listrik serta LCD proyektor. Terkait dengan permasalahan tersebut, penulis sebagai kepala sekolah perlu melakukan perbaikan terhadap kondisi yang terjadi. Karena sudah merupakan tugas kepala sekolah mengarahkan peserta didik serta guru harus selalu inovatif dalam proses pembelajaran. Setiap sekolah melalui kepala sekolah wajib melakukan pembinaan dalam rangka mengatasi permasalahan-permasalahan yang dijumpai guru dalam pembelajaran dan penilaian (Tingkat, 2020).

Salah satu cara yang dapat dilakukan kepala sekolah sebagai solusi adalah melakukan proses supervisi dalam pembelajaran.secara sederhana kegiatan supervisi dapat diartikan melihat dari atas, atau atasan melakukan pengawasan. Menurut Bahri (2014) supervisi akademik merupakan upaya membantu guru-guru mengembangkan kemampuannya mencapai tujuan akademik. Dalam kegiatan supervisi dilakukan pengawasan terhadap guru dalam pembelajaran agar sesuai dengan pembelajaran termasuk juga dapat dilakukan untuk memotivasi guru agar mengembangkan pemanfaatan media pembelajaran yang digunakan dalam pembelajaran. Penelitian terdahulu yang dijadikan referensi adalah hasil penelitian Lalupanda (2019) yang dalam hasil penelitiannya menyatakan bahwa peran dari kepala sekolah dalam kegiatan di sekolah sangat besar sehingga dapat membantu sekolah dalam mencapai tujuan bersama. Salah satu cara yang dapat dilakukan oleh kepala sekolah dalam meningkatkan pencapaian yang dilakukan guru dalam proses pembelajaran adalah membangun komunikasi dengan para guru melalui kegiatan supervise akademik.

Berkaitan dengan permasalahan tersebut di atas, perlu dilaksanakan penelitian tindakan sekolah guna mengatasi masih belum optimalnya pemanfaatan media pembelajarna berbasis IT oleh para guru. Penelitian ini bertujuan untuk mengetahui optimalisasi pemanfaatan media IT dalam pembelajaran pada guru SMP Negeri 3 Pupuan melalui pelaksanaan kegiatan supervisi pembelajaran yang dilakukan secara berkala oleh kepala sekolah. Dengan dilaksanakannya penelitian tindakan sekolah ini dapat meningkatkan pemanfaatan media IT dalam pembelajaran baik dari segi kuantitas atau jumlah guru yang memanfaatkan media IT dalam pembelajaran serta intensitas atau frekuensi pemanfaatannya dikalangan guru SMP Negeri 3 Pupuan dengan dilakukannya kegiatan supervisi

\section{METODE PENELITIAN}

Penelitian ini adalah penelitian tindakan sekolah yang dilakukan di SMP Negeri 3 Pupuan pada Bulan Januari sampai Juni 2020. Subjek penelitian ini adalah semua guru di SMP Negeri 3 Pupuan yaitu sebanyak 15 orang, sedangkan objek penelitian adalah pemanfaatan media IT dalam pembelajaran. Adapun kriteria keberhasilan dalam penelitian ini adalah guru mampu memanfaatkan media IT dalam pembelajaran, dengan jumlah guru yang menerapkan IT dalam pembelajaran minimal $80 \%$ dan minimal $80 \%$ guru yang mengajar di 
SMP Negeri 3 Pupuan sering memanfaatkkan media IT dalam menunjang pembelajaran di kelas. Tehnik pengumpulan data dalam penelitian tindakan sekolah ini adalah dengan observasi dan kuesioner. Alat pengumpulan adalah lembar pengamatan dan kuesioner. Data yang diperoleh akan dianalisis deskriptif kualitatif.

Kegiatan dalam penelitian ini dilakukan secara siklusitis dimana setiap siklusnya terdiri dari kegiatan perencanaan, observasi dan refleksi. Dalam upaya meningkatkan pemanfaatan media IT dalam pembelajaran pada SMP Negeri 3 Pupuan hal yang dipersiapkan adalah menyampaikan informasi tentang pemanfaatan media IT dalam pembelajaran dan untuk memotivasi para guru melakukan hal tersebut akan dilakukan kegiatan supervisi pembelajaran terutama dalam hal pemanfaatan media penunjang kegiatan pembelajaran yang dilakukan guru. Guna menunjang kemampuan guru tidak dilakukan pelatihan secara formal namun agar lebih efektif dan efisien akan lebih mengoptimalkan kolaborasi dikalangan guru sehingga saling melengkapi dan memotivasi satu sama lain guna mempersiapkan media yang akan digunakan. Diharapkan dengan dilakukan kegiatan supervisi oleh kepala sekolah para guru dapat mengoptimalkan kreatifitasnya dalam menyusun media IT serta memanfaatkanannya dalam pembelajaran. Kegiatan dilaksanakan sesuai dengan perencanaan yang telah disusun

\section{HASIL DAN PEMBAHASAN}

Sebelum melaksanakan penelitian pada subjek penelitian yang merupakan guru-guru pada SMP Negeri 3 Pupuan, sebagai tahap awal disampaikan hasil supervisi pembelajaran yang telah dilakukan berdasarkan pelaksanaan pembelajaran pada semester ganjil tahun pelajaran 2019/2020. Dalam kegiatan pembelajaran pada semester ganjil tahun pelajaran 2019/2020 diketahui bahwa pemanfaatan media IT dalam pembelajaran masih belum maksimal sehingga dilaksanakan pertemuan pada tanggal 3 Januari 2020. Dalam pertemuan tersebut disampaikan saran bagi para guru agar meningkatkan pemanfaatan media IT dalam pembelajaran sehingga dapat membantu siswa memahami pembelajaran dan dapat memudahkan guru dalam melaksanakan pembelajaran

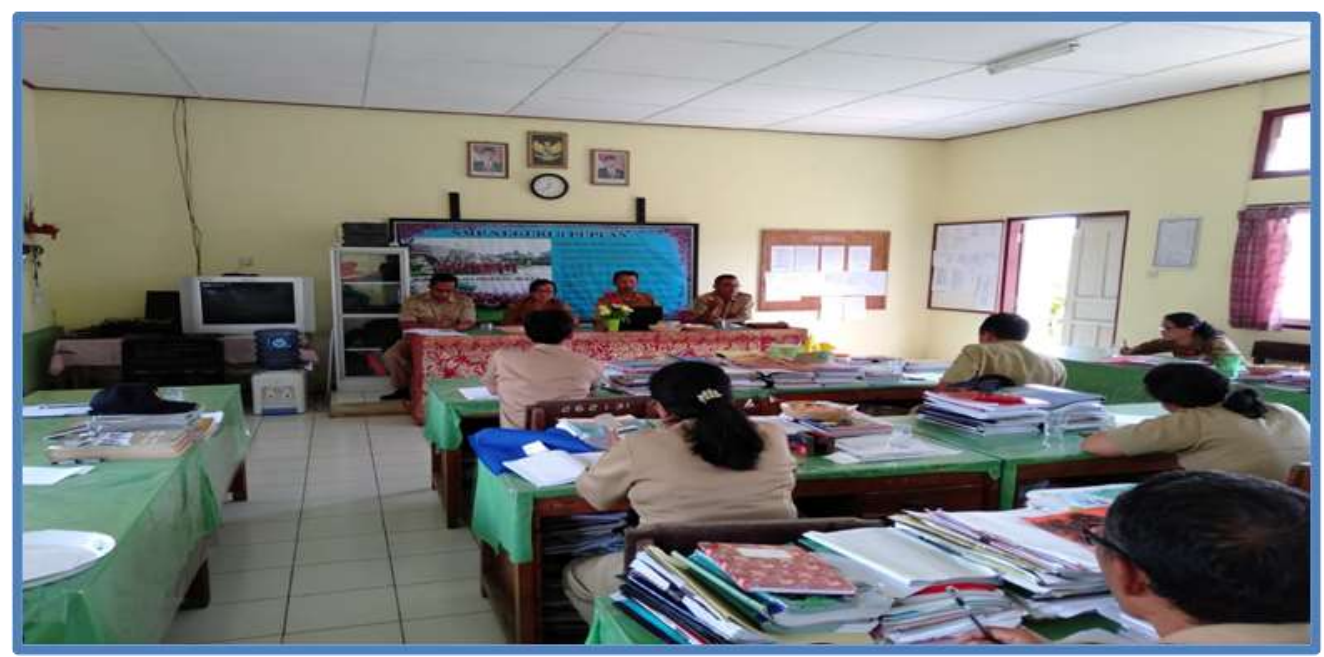

Gambar 1. Pertemuan Awal Dengan Para Guru

Dari pertemuan awal tersebut disampaikan rencana kegiatan penelitian tindakan sekolah dalam bentuk pemanfaatan media IT dalam pembelajaran dan akan dilakukan supervisi secara berkala guna memotivasi dan melihat perkembangan guru dalam memanfaatkan media IT dalam pembelajaran. Diharapkan bagi guru-guru yang sudah 
terbiasa memanfaatkan media IT dalam pembelajaran agar berkolaborasi dan saling membantu guru-guru lainnya dalam memanfaatkan fasilitas yang ada guna menunjang pembelajaran. Kegiatan penelitian tindakan ini dilaksanakan dalam dua siklus sesuai perencanaan yang sudah ditetapkan.

\section{Gambaran Kondisi Pra-Siklus}

Kondisi yang diperoleh dalam kegiatan pra siklus, adalah kondisi yang didapat berdasarkan kondisi pemanfaatan media dan frekuensi pembelajaran pada semester ganjil tahun pelajaran 2019/2020 dimana pada kondisi ini diperoleh data sesuai Tabel 2

Tabel 2. Data Pemanfaatan Media IT dalam Pembelajaran pada Pra-Siklus

\begin{tabular}{cccc}
\hline No & Pemanfaatan Media Pembelajaran & Jumlah & Persentase \\
\hline 1 & Memanfaatkan Media IT & 9 Orang & $60 \%$ \\
2 & Tidak Memanfaatkan Media IT & 6 Orang & $40 \%$ \\
\hline & Jumlah Guru & 15 Orang & $100 \%$ \\
\hline
\end{tabular}

Berdasarkan data tersebut, dapat diketahui bahwa hanya 9 orang guru dari 15 guru SMP Negeri 3 Pupuan yang memanfaatkan media IT dalam pembelajaran. jika dilihat dari frekuensi pemanfaatan media IT dalam pembelajaran, jumlah guru yang sering memanfaatkan media IT dalam pembelajaran hanya 6 orang atau sebesar $40 \%$, hal ini terjadi karena guru cenderung lebih memanfaatkan dan mengoptimalkan buku paket sebagai media utama dalam pembelajaran. Hal ini perlu diperbaiki dalam bentuk penelitian tindakan sekolah agar guru-guru dapat mengoptimalkan pemanfaatan media IT dalam pembelajaran.

\section{Pelaksanaan Tindakan Siklus I}

Sesuai dengan perencanaan yang dipersiapkan sebagai tindakan awal dilaksanakan kolaborasi anatar guru untuk saling membantu guna memahami, memilih termasuk juga mempersiapkan media IT yang akan digunakan dalam pembelajaran. Bentuk kolaborasi yang dilakukan adalah dengan meminta guru yang sudah terbiasa memanfaatkan media bebasis IT untuk memberikan motivasi serta membantu guru-guru lainnya untuk mempersiapkan media yang ingin digunakan dalam menunjang kegiatan pembelajaran. Selain hal tersebut juga dilakukan supervisi dari kepala sekolah dalam pembelajaran yang dilakukan oleh para guru agar mulai memanfaatkan media IT dalam pembelajaran. Berdasarkan kegiatan kolaborasi yang dilakukan guru-guru tertarik memanfaatkan media power point dalam pembelajaran hal ini juga sesuai dengan fasilitas yang dimiliki para guru berupa laptop serta fasilitas LCD proyektor yang dimiliki oleh sekolah dan secara berkala dilaksanakan supervisi ke kelas guna memotivasi guru-guru dalam pembelajaran sesuai dengan perencanaan dan media yang sudah disusun. Berdasarkan hasil observasi dan angket yang diberikan kepada para guru diperoleh data pemanfaatan media IT dalam pembelajaran di kelas yang dilaksanakan oleh guru-guru pada SMP Negeri 3 Pupuan sesuai Tabel 3

Tabel 3. Data Pemanfaatan Media IT dalam Pembelajaran

\begin{tabular}{clcc}
\hline No & Pemanfaatan Media Pembelajaran & Jumlah & Persentase \\
\hline 1 & Memanfaatkan Media IT & 14 Orang & $93,33 \%$ \\
2 & Tidak Memanfaatkan Media IT & 1 Orang & $6,67 \%$ \\
\hline & Jumlah Guru & 15 Orang & $100 \%$ \\
\hline
\end{tabular}

Berdasarkan Tabel 3. di atas, pada Siklus I jumlah guru yang menggunakan media IT dalam pembelajaran sebanyak 14 orang guru atau sebesar 93,33\% dan guru yang belum 
memanfaatkan media IT dalam pembelajaran sebanyak 1 orang guru atau sebesar 6,67\%. Jika dilihat dari frekuensi pemanfaatan media IT dalam pembelajaran sebanyak 9 orang guru atau sebesar $60 \%$ sering memanfaatkan media IT dalam pembelajaran selama siklusi I penelitian ini. Jika dilihat dari kriteria keberhasilan terkait dengan jumlah guru yang memanfaatkan media IT sudah memenuhi kriteria di atas $80 \%$, namun dilihat dari intensitas pemanfaatan media IT dalam pembelajaran belum memenuhi $80 \%$, sehingga penelitian tindakan ini akan dilanjutkan pada siklus II. Terkait dengan frekuensi pemanfaatan media IT dalam pembelajaran yang dilakukan oleh guru-guru SMP Negeri 3 Pupuan dapat dilihat pada Tabel 4.

Tabel 4. Data Frekunsi Pemanfaatan Media IT dalam Pembelajaran

\begin{tabular}{cccc}
\hline No & Pemanfaatan Media Pembelajaran & Jumlah & Persentase \\
\hline 1 & Sering Memanfaatkan Media IT & 9 Orang & $60 \%$ \\
2 & Jarang Memanfaatkan Media IT & 5 Orang & $33 \%$ \\
3 & Tidak Memanfaatkan Media IT & 1 Orang & $7 \%$ \\
\hline & Jumlah Guru & 15 Orang & $100 \%$ \\
\hline
\end{tabular}

Pada pelaksanaan siklus I ini terdapat beberapa hal yang mendukung antara lain dengan pelaksanaan kolaborasi antar guru-guru dalam pemanfaatann terutama saling berbagi informasi tentang pemanfaatan media IT dalam pembelajaran menyebabkan guru-guru mulai memanfaatkan dan menyusun sendiri media IT dalam pembelajaran. karena tidak melalui platihan yang sifatnya formal jadi lebih mudah guru-guru untuk saling bertanya dengan guru yang lainnya sehingga upaya ini juga dapat meningkatkan komunikasi dikalangan guru smp Negeri 3 Pupuan. Ditambah lagi dengan dilaksanakan supervisi secara berkala ke kelas dan komunikasi antara kepala sekolah dapat meningkatkan jumlah guru yang memanfaatkan media IT dalam pembelajaran

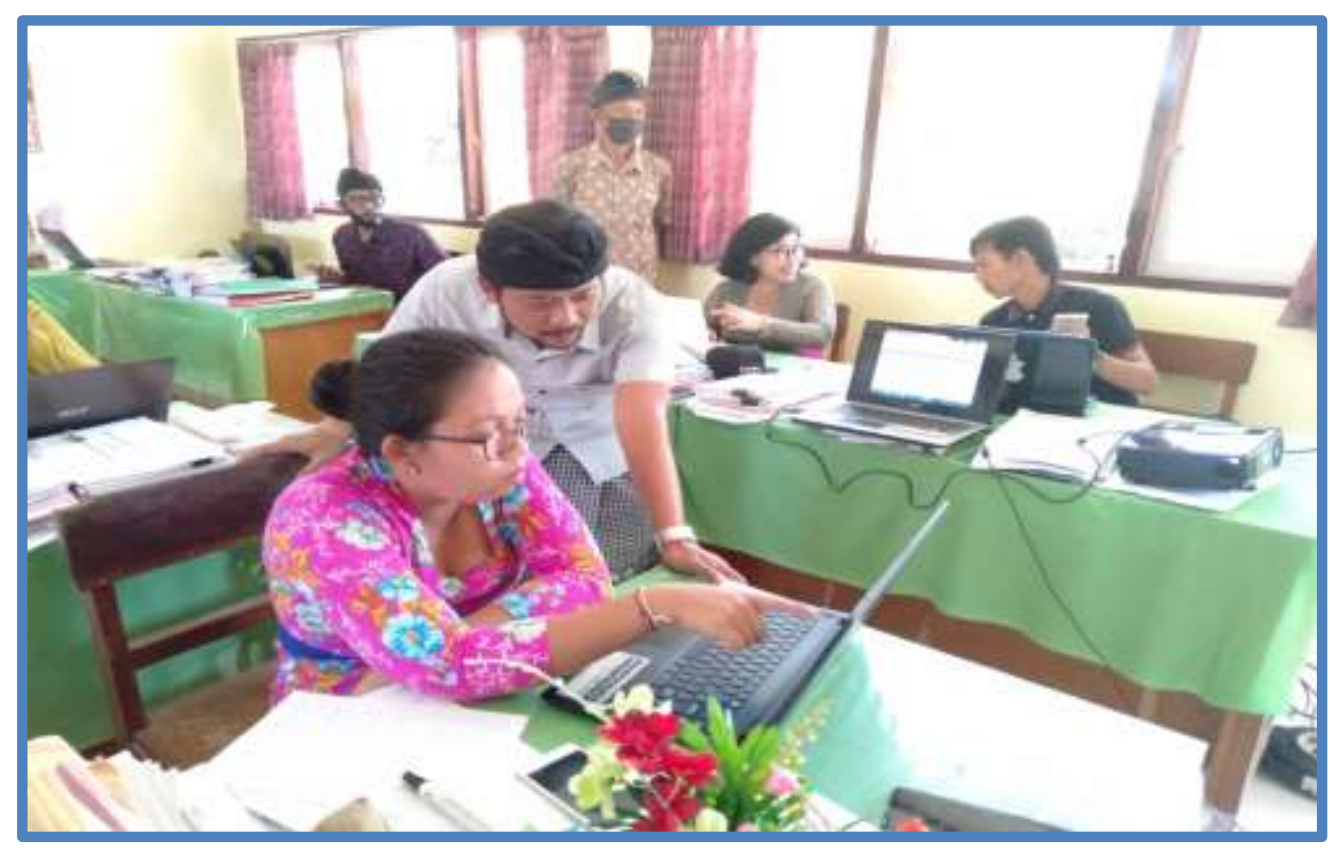

Gambar 2. Kolaborasi antar guru tentang pemanfaatan media IT

Kendala dalam siklus I tidak begitu berarti namun karena baru mulai dilaksanakan waktu yang dimiliki guru masih terbatas, sehingga jika dilihat dari frekuensi pemanfaatan 
media IT dalam pembelajaran khususnya pemanfaatan media powerpoint masih belum dapat maksimal atau sering dilakukan oleh para guru pada siklus ini. Selain itu, terdapat 1 guru yang belum memanfaatkan media IT karena terkendala usia sehingga perlu waktu untuk memanfaatkan media tersebut dalam pembelajaran. Hal tersebut akan diperbaiki pada siklus II sehingga dapat membantu memenuhi kriteria keberhasilan yang telah ditetapkan dalam penelitian tindakan ini.

\section{Pelaksanaan Tindakan Siklus II}

Pelaksanaan siklus II dalam penelitian tindakan ini diawali dari refleksi siklus I. upaya perbaikan yang dilakukan pada siklus II disampaikan dalam pertemuan dengan para guru SMP negeri 3 Pupuan pada tanggal 18 Februari 2020. Hal yang disampaikan tersebut antara lain pemanfaatan waktu oleh guru untuk mempersiapkan media pembelajaran yang akan digunakan sehingga intensitas guru dalam memanfaatkan media IT dalam pembelajaran dapat ditingkatkan. Selain hal tersebut juga diharapkan guru dapat memanfaatkan media IT yang menarik bagi siswa sehingga pembelajaran dapat berjalan dengan lebih menarik.

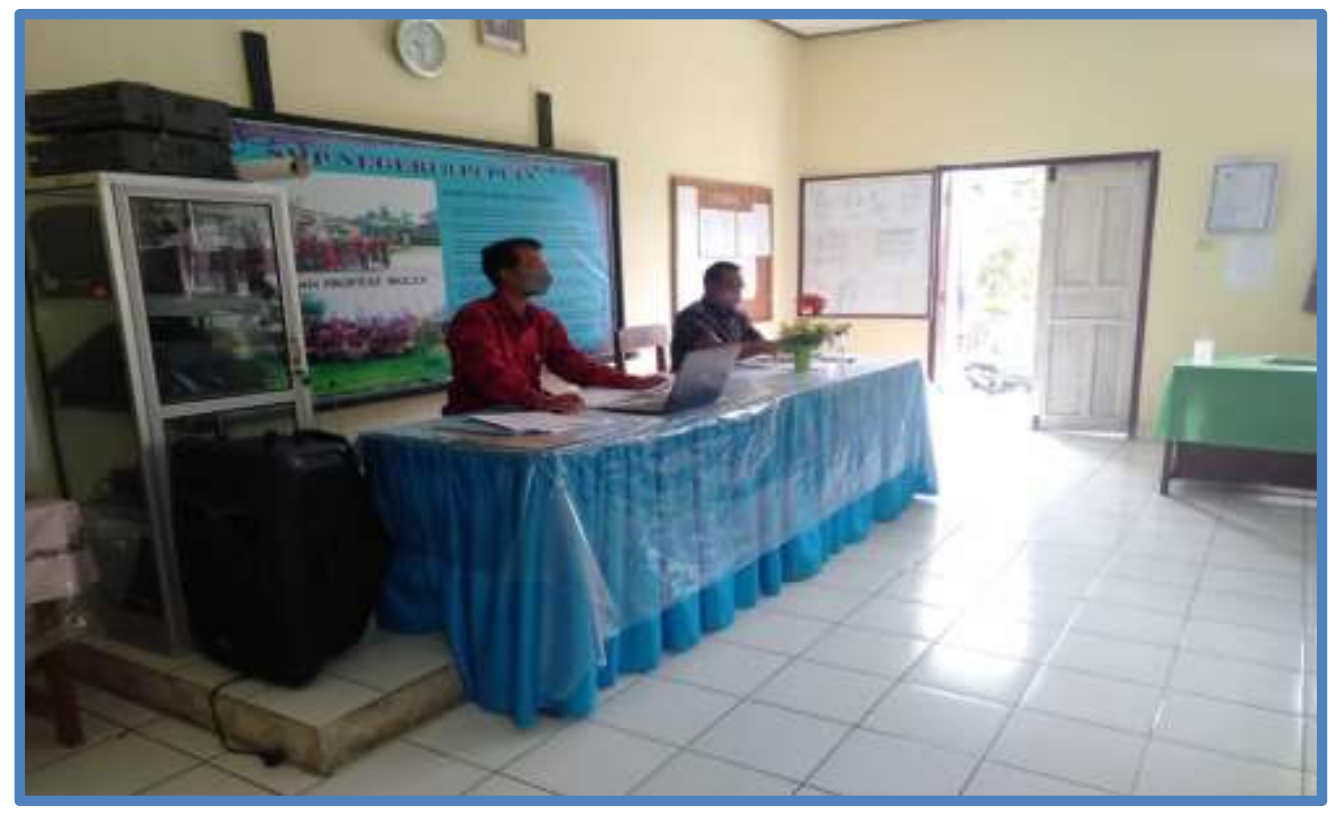

Gambar 3. Pertemuan persiapan siklus II

Setelah pelaksanaan supervisi terhadap pembelajaran yang dilakukan oleh para guru pada siklus II, diperoleh data pemanfaatan media IT dalam pembelajaran sesuai pada Tabel 5. berikut ini.

Tabel 5. Data frekunsi pemanfaatan media IT dalam pembelajaran pada siklus II

\begin{tabular}{cccc}
\hline No & Pemanfaatan Media Pembelajaran & Jumlah & Persentase \\
\hline 1 & Memanfaatkan Media IT & 14 Orang & $93,33 \%$ \\
2 & Tidak Memanfaatkan Media IT & 1 Orang & $6,67 \%$ \\
\hline & Jumlah Guru & 15 Orang & $100 \%$ \\
\hline
\end{tabular}

Berdasarkan tabel 5. di atas, dalam siklus II jumlah guru yang memanfaatkan media IT sebanyak 14 orang atau sebesar 93,33\%. Ini tidak berubah dari hasil yang diperoleh pada siklus I, namun hal tersebut sudah memenuhi kriteria keberhasilan yang ditetapkan yaitu sebesar $80 \%$ guru memanfaatkan media IT dalam pembelajaran. namun jika dilihat dari 
frekuensi pemanfaatan media IT pada siklus II diperoleh data bahwa sebanyak 12 orang guru atau $80 \%$ sudah sering memanfaatkan media IT dalam pembelajaran. hal ini sudah sesuai dengan kriteria keberhasilan yang ditetapkan yaitu sebesar $80 \%$ guru sering memanfaatkan media IT dalam pembelajaran. Terkait dengan data frekuensi pemanfaatan media IT dalam pembelajaran dapat dilihat pada tabel 6 .

Tabel 6. Data frekunsi pemanfaatan media IT dalam pembelajaran pada siklus II

\begin{tabular}{cccc}
\hline No & Pemanfaatan Media Pembelajaran & Jumlah & Persentase \\
\hline 1 & Sering Memanfaatkan Media IT & 12 Orang & $80 \%$ \\
2 & Jarang Memanfaatkan Media IT & 2 Orang & $13 \%$ \\
3 & Tidak Memanfaatkan Media IT & 1 Orang & $7 \%$ \\
\hline & Jumlah Guru & 15 Orang & $100 \%$ \\
\hline
\end{tabular}

Hasil yang dicapai pada siklus II ini tidak dapat dilepaskan dari peran kepala sekolah dalam memotivasi para guru dalam kegiatan supervisi pembelajaran sehingga meningkatkan frekuensi pemanfaatan media IT dalam pembelajaran yang dilakukan oleh para guru. Disamping itu media yang digunakan oleh para guru juga semakin menarik sehingga membantu siswa dalam meningkatkan fokus dan pemahaman terhadap materi pembelajaran yang di ikuti

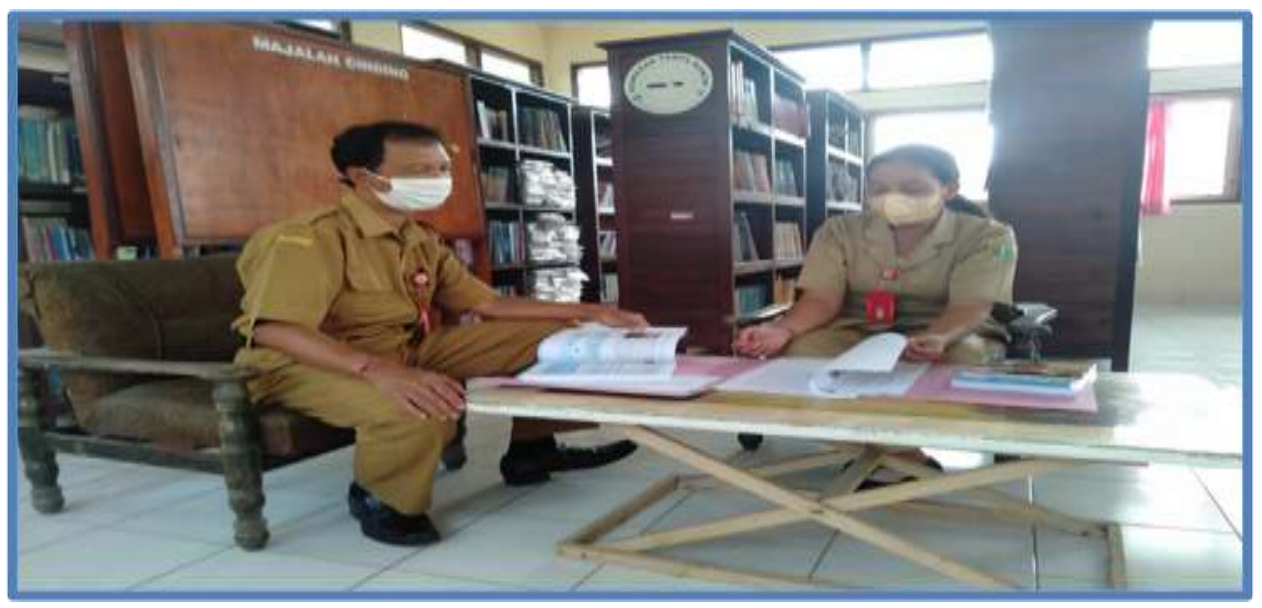

Gambar 4. Pelaksanaan supervisi

Jika dilihat secara umum, peningkatan pemanfaatan media IT oleh guru dalam proses pembelajaran meningkat dari pra siklus sebanyak 6 orang (60\%) guru yang memanfaatkan IT dalam Pembelajaran meningkat pada siklus I menjadi 14 orang $(93,33 \%)$ guru yang memanfaatkan Media IT dalam Pembelajaran dan pada siklus II sejumlah 14 orang $(93,33 \%)$ guru yang memanfaatkan Media IT dalam Pembelajaran. jika dilihat dari intensitas pemanfaatan media IT dalam pembelajaran dari siklus I sebanyak 9 Orang guru yang sering memanfaatkan IT dan meningkat pada siklus II menjadi 12 orang guru (80\%) sering memanfaatkan IT dalam proses pembelajaran. hal ini menunjukkan bahwa kriteria keberhasilan mulai dari pemanfaatan media IT dan frekuaensi pemanfaatan media IT dalam pembelajaran dapat terpenuhi. Sehingga penelitian tindakan sekolah ini dapat dikatakan berhasil. Hal ini sesuai dengan pendapat dari Tingkat (2020) yang menyatakan bahwa kepala sekolah dapat membantu para guru dalam menyelesaikan permasalahan yang ada terkait pembelajaran, selanjutnya hal ini juga sesuai dengan hasil penelitian dari Lalupanda (2019) yang dalam hasil penelitiannya menyatakan bahwa peran dari kepala sekolah dalam kegiatan 
di sekolah sangat besar sehingga dapat membantu sekolah dalam mencapai tujuan bersama. Salah satu cara yang dapat dilakukan oleh kepala sekolah dalam meningkatkan pencapaian yang dilakukan guru dalam proses pembelajaran adalah membangun komunikasi dengan para guru melalui kegiatan supervisi akademik agar perencanaan yang dilakukan sesuai dengan kegiatan yang dilaksanakan guru. Termasuk juga dalam pemanfaatan media pembelajaran berbasis IT dalam pembelajaran dengan supervise yang didalamnya juga terdapat kegiatan observasi dapat mengoptimalkan dan memacu guru dalam memanfaatkan media IT dalam pembelajaran

\section{KESIMPULAN DAN SARAN}

Berdasarkan hasil dan pembahasan di atas dapat disimpulkan bahwa pelaksanaan supervise oleh kepala sekolah dapat meningkatkan pemanfaatan media IT dalam pembelajaran yang dilakukan oleh para guru SMP Negeri 3 Pupuan, hal tersebut dapat dilihat dari peningkatan jumlah guru yang memanfaatkan media IT dari tahapan Pra Siklus, Siklus I dan Siklus II, termasuk juga peningkatan jumlah frekuensi pemanfaatan media IT dalam pembelajaran yang dilaksanakan guru. Hal ini tidak terlepas dari komunikasi yang dibangun kepala sekolah dalam pelaksanaan supervisi pembelajaran termasuk juga terkait dengan pemanfaatan media pembelajran yang digunakan guru.

Terkait dengan hasil penelitian tindakan ini dapat disampaikan saran bagi para guru agar dapat memanfaatkan media IT dalam pembelajran sehingga dapat menjadi contoh bagi siswa dan dapat membantu siswa untuk memahami pembelajaran melalui media yang digunakan. Selain itu, bagi kepala sekolah yang mengalami kendala dalam pencapaian program sekolah dapat mengoptimalkan kegiatan supervise tentunya dengan komunikasi yang baik didalamnya sehingga membantu pencapaian perencanaan yang telah ditetapkan sekolah.

\section{UCAPAN TERIMAKASIH}

Terkait dengan terlaksananya penelitian tindakan sekolah ini tidak lupa kami sampaikan ucapan terimakasih kepada Pengawas Sekolah SMP Negeri 3 Pupuan beserta para guru atas dukungan yang diberikan sehingga penelitian tindakan sekolah ini dapat terselesaikan dan semoga kerjasama dalam upaya membangun SMP Negeri 3 Pupuan kedepannya dapat kita Optimalkan dengan usaha bersama

\section{DAFTAR PUSTAKA}

Abdullah, R. (2016). Pembelajaran dalam perspektif kreativitas guru dalam pemanfaatan media pembelajaran. Lantanida Journal, 4(1), 35-49. https://jurnal.ar-raniry.ac.id/index.php/lantanida/article/view/1866/1387

Anisa, F \& Yuliyanti, E. (2017). Analisis faktor yang mempengaruhi pembelajaran kimia di sma teuku umar semarang. Prosiding Seminar Nasional Pendidikan, Sains dan Teknologi Fakultas Matematika dan Ilmu Pengetahuan Alam Universitas Muhammadiyah Semarang, 476-482. https://jurnal.unimus.ac.id/index.php/psn12012010/article/view/3138.

Audie, N. (2019). Peran media pembelajaran meningkatkan hasil belajar peserta didik. Prosiding Seminar Nasional Pendidikan FKIP Universitas Sultan Ageng Tirtayasa, 2(1), 586-595. https://jurnal.untirta.ac.id/index.php/psnp/article/view/5665/4066. 
Bahri, S. (2014). Supervisi akademik dalam peningkatan profesionalisme guru. Visipena, 5(1), 100-112. https://ejournal.bbg.ac.id/visipena/article/view/236.

Iskandar, U. (2013). Kepemimpinan kepala sekolah dalam meningkatkan kinerja guru. Jurnal Visi Ilmu Pendidikan, 10(1), 1018-1022. https://jurnal.untan.ac.id/index.php/jvip/article/view/2061/2002.

Lalupanda, E. M. (2019). Implementasi supervisi akademik untuk meningkatkan mutu guru. Jurnal Akuntabilitas Manajemen Pendidikan, 7(1), 62-72. https://journal.uny.ac.id/index.php/jamp/article/view/22276/11981.

Nurseto, T. (2011). Membuat media pembelajaran yang menarik. Jurnal Ekonomi \& Pendidikan, $8(1)$

19-35. https://journal.uny.ac.id/index.php/jep/article/view/706/570.

Rusman. (2012). Pembelajaran Berbasis tik. Jakarta: PT.Raja Grafindo Persada.

Suryani, N. (2016). Pengembangan media pembelajaran sejarah berbasis it. Jurnal Sejarah dan Budaya, 10(2), 186-196. http://journal.um.ac.id/index.php/sejarahdan-budaya/article/view/7669.

Tingkat, I. N. (2020). Optimalisasi pengembangan diri untuk mendongkrak prestasi (vokasional) sekolah. Indonesian Journal of Educational Development, 1(1), 1-12. https://doi.org/10.5281/zenodo.3760422.

Vandini, I. (2015). Peran kepercayaan diri terhadap prestasi belajar matematika siswa. Jurnal Formatif, 5(3), 210-219. https://journal.lppmunindra.ac.id/index.php/Formatif/article/view/646/573. 